\title{
The Organisation of Scientific Research at Leszczyński’s Academy in Nancy
}

\section{MAŁGORZATA DURBAS}

During the modern era the need for knowledge and searching for truths connecting extraordinary minds of science started to become formalized by institutionalization which was - and is - one of the most important processes of the regulation of social life. The ideas of the English philosopher Francis Bacon presented in his work New Atlantis (1627) were of great importance in this process. He showed that science can and must be organized and used in practice and industry. The practical application of sciences would improve life conditions. ${ }^{1}$ Bacon insisted that the broad field of natural knowledge was too large for one man. Collecting information, which was the first step towards a scientific investigation of the laws of nature, had become so complicated by then, that is was only possible as a collective enterprise. ${ }^{2}$

In France, the process of institutionalization of scientific research was in the full swing. Groups of highly educated scholars eager to analyse their scientific discoveries and take part in intellectual disputes were created more frequently than ever before. Academies and scientific societies established in $18^{\text {th }}$ century were a significant phenomenon of intellectual life not only in France, but in many European countries as well. They were set up as public institutions working for the state in the field of sciences and humanities in order to develop cooperation between scholars, exchange thoughts and achievements and create the workspace for scientific experiments. The day before the French revolution, 32 cities (without Paris) had one or more academic institutions ${ }^{3}$. Between 1715 and 1760, the provincial academic movement acquired twenty new centers including Stanisław Leszczyński's Academy in Nancy. It was established rather late in comparison to other scientific institutions in French provincial cities such as Dijon (1725), Marseille (1726), Arras (1737), Rouen (1744), Toulouse (1730) or Amiens (1746) 4 .

The Polish king, Stanisław Leszczyński, the duke of Lorraine and Bar created a formal institution with strict rules

1 James Gunn, Droga do science fiction I. Od Gilgamasza do Wellsa, Warsaw 1985, p. 88; Nova Atlantis per Franciscum Baconum Baronem de Verulamio, vice-Comitem St. Albani, Utrechti 1643.

2 Rupert Hall, Rewolucja naukowa 1500-1800, Warszawa 1966, p. 223.

3 Gérard Michaux, Naissance et developpement des académies en France aux XVII et XVIII siecle, in: Mémoires de l'Académie Nationale de Metz, Metz 2008, p. 82.

4 IBIDEM. 
working for the socio-economic sector. ${ }^{5}$ The establishment was triggered by the political changes connected with the War of the Polish Succession (1733-1735). It is important to consider that the academy in Nancy was the result of Leszczyński's modernisation efforts in Lorraine and Bar. They were meant to be a part of his charity system $^{6}$. Stanisław Leszczyński Academy in Nancy is the most successful of all the king's establishments. It has continued to work since then with only one interruption during the French Revolution.

It was founded by the edict of December 28,1750 , as a part of the public library in the form of two contest prizes for scientific theses. ${ }^{7}$ In the beginning, it was called Société Royale des Sciences et Belles-Lettres in Nancy. ${ }^{8}$ After a hundred years it became Stanistaw Leszczyński Academy. ${ }^{9}$ As one of the many similar institutions in France and Europe its main aim was to propagate science in various disciplines and to exchange ideas between academicians. The aim of this article is to explain the organization of research activities and analyse scholarly competitions in Société Royale des Sciences et Belles-Lettres (Stanisław Leszczyński Academy) founded by the Polish king and the duke of Lorraine and Bar, Stanisław Leszczyński.

The Statute of Academy ${ }^{10}$ from 1751 provided legal frameworks for the new organisation unit. It regulated its structure and outlined its tasks and its manner of operation. The Statute consists of 44 articles. Every article is related to a different question vital for the work of the Society. New members of the institution were first called „censors“ and later „academicians". According to the Statute, the Society consisted of forty members: five

The second election of the king Stanisław Leszczyński in 1733 was the cause of the War of the Polish Succession declared by France against the Habsburg Empire. The duchy of Lorraine and Bar was one of the causes of the war, because they were supposed to become the property of the Empire after the marriage between the duke Francis Stephen and the daughter of Charles VI, Maria Theresa. King Stanisław was offered Lorraine and Bar in exchange for signing the act of abdication. After his death these duchies would be given to the Bourbons. The negotiations finished with the third Treaty of Vienna. King Stanisław ruled Lorraine and Bar for 29 years. See Pierre Boyé, Stanislas Leszczyński et le troisième traité de Vienne, Nancy 1898; Małgorzata Durbas, Ważnośc drugiej elekcji króla Stanistaw a Leszczyńskiego w świetle trzeciego traktatu wiedeńskiego in: Andrzej Markiewicz - Dariusz Rolnik - Filip Wolański (edd.), Wokół wolnych elekcji w państwie polsko-litewskim XVI-XVIII wieku. O znaczeniu idei wyboru - między prawami a obowiązkami, Katowice 2016.

6 The king Stanisław Leszczyński founded 29 charity institutions there. See Précis des fondations et etablissements, fait par sa Majesté le Roi de Pologne, Duc de Lorraine et de Bar, Nancy 1758.

$7 \quad$ Edit du Roy portant établissement d'une Bibliothèque publique à Nancy et fondation de deux Prix, Nancy 1751; reprinted in Mémoires de la Société Royale des Sciences et Belles-Lettres de Nancy (later Mémoires de la Société Royale) I, Nancy 1754, p. 3-11.

$8 \quad$ Statuts de la Société Royale des Sciences et Belles Lettres de Nancy, Nancy 1751; see Statuts de la Société Royale des Sciences, reprinted in Mémoires de la Société Royale I, p. 83-104.

9 Małgorzata Durbas, Akademia Stanistaw a w Nancy (1750-1766), Kraków 2013.

$10 \quad$ Statuts, p. 83-104. 
censors with a fixed salary, described as academicians ${ }^{11}$, twelve honorary members, fifteen titular members living in Nancy and eight foreign members. Saint Stanislaus of Szczepanów, the bishop of Cracow, became the patron of the Society. The Society's managing body was composed of three officials: the managing director, his deputy (both elected by secret vote every year on Thursday after the Epiphany) and a perpetual secretary, who was also the main librarian and functioned in both positions until his death. ${ }^{12}$ The director had to preside over the sessions, choose their topics and follow the Statute. The secretary was supposed to sign and seal the documents, record the sessions and conduct the correspondence with associated academicians. As a librarian he was charged with the administration of the book collection. He was also obligated to write financial reports and submit them to a special commissary. The Statute regulated the terms of electing members for the free seats. It regulated also the procedure of selecting foreign members. They were supposed to give a reception speech. The
Statute determined the order of seats during public sessions, regulated the rights of academicians in case of long-term business trips. The Society had a printing privilege for choosing the name and place of the printing house. According to the statute, academicians met in ordinary and extraordinary sessions in Galerie des Cerfs du Palais Ducal. ${ }^{13}$ It was a representative palace hall, where the estates general used to convene but at that time the hall was used just for representation and entertainment. ${ }^{14}$ For example, in 1699 , there was a party at the occasion of the wedding of the archduke Joseph, the cousin of Leopold and future emperor. After thirteen years the king Stanisław found better rooms for the Academy in the new building of the town hall, l'Hôtel de Ville. The town hall was a part of a complex of buildings near the king's palace in Nancy. In the Ordonnance du Roi from 1763, the founder decided that the ordinary sessions would take place in one of library's halls and public meetings in the representative room called the Grand Salon (Salon Carrê).${ }^{15}$

11 Iвidem, p. 85.

12 Pierre-Joseph Lapimpie, Chevalier de Solignac (1684-1773), the official secretary of Polish king, the duke of Lorraine and Bar, Stanisław Leszczyński between 1737-1766 and the first perpetual secretary of the Academy in Nancy. See Małgorzata Durbas, Les étranges relations du chevalier de Solignac en Pologne, La Pays Lorrain. Revue régionale bi-mensuelle illustrée, 108 année, vol. 92, 2011, p. 133-140; Małgorzata Durbas, Sekretarz króla Stanistaw a Leszczyńskiego, P. J. De Solignac, agent czy wierny stuga, in: Zbigniew Anusik (ed.), Władza i polityka w czasach nowożytnych, Łódź 2011, p. 131-147.

13 Guy Cabourdin, Encyclopédie illustrée de la Lorraine, De la paix de Westphalie à la fin de l'Ancien régime II, Nancy 1991, p. 79, 88. IвIDEM.

15 Ordonnance du Roi concernant la Bibliothèque Publique de Nancy du 27 juin 1763, in: Société Royale des Lettres, Sciences et Arts de Nancy - procès-verbaux, ms.1759-1765, vol. III, p. 524-526. 
Every year the Society organized a contest and awarded two prizes of 600 livres in science and literature for the nationals of Lorraine. The contestants were supposed to submit three copies of the text to the secretary of the Society in September of each year. The text was not signed with name but with a sequence of words known only to the author. The perpetual secretary registered the works with particular numbers and gave a certification of the admission. On the first Thursday of October, the secretary presented the works to the members during the meeting and after the approval of the managing director members decided which works would be rejected. ${ }^{16}$

During the following sessions the selected works were divided into different disciplines of science and literature. The copies of the prize essays were distributed among three different academicians according to their discipline in such a way that they were unable to communicate with each other or share opinions. After the next selection made on the basis of reviews of the contesting texts, The Royal Society selected the works which could receive the prize. The academicians were ordered to keep the whole procedure a secret. ${ }^{17}$

The members of the Royal Society of Sciences and Literature in Nancy were not allowed to submit their works to the prize contest under the threat of exclusion from the academy. The works chosen for the prize were supposed to display innovative ideas, creative talents and correct language in case that they were literary works. Authors who had published their works elsewhere, or authors who were too eager to win were excluded from the prize contest. After the verdict about the best texts, but before the official announcements, the secretary opened the sealed document with the names of the authors to check their nationality. The official verdict and the announcement of the award were supposed to take place during the public session on the first Thursday after Epiphany. The winners, according to the article XXX of the Statute, were obligated to provide their portraits with their name, the title of the work and date at the bottom of the picture. The portraits were hung in the public library in order to develop intellectual interests in the people of Lorraine and encourage them to take part in such competitions. This was the idea of the king Stanisław, the founder of the institution.

The Statute precisely determined the schedule of the meetings of the Society. The ordinary sessions took place every Thursday between 2 and 5 p.m. except during summer holidays from August 15 until the end of September. ${ }^{18}$ There were also three

16 Statuts, p. 89.

17 IвIDEM, p. 90.

18 In practice, the frequency of sessions differed from the statutes. In the beginning, ordinary and extraordinary sessions took place on Thursday afternoon, except for holidays. From 1756 onwards, the members met every two weeks in the summer and once a month in the winter. This regulation was ordered by the secretary. However, the regulation was not always observed due to various interfering circumstances. See M. Durbas, Akademia Stanistaw a, p. 110. 
breaks for church holidays: two weeks during Easter, one week of Pentecost and the time around Christmas to Epiphany. If the holiday was on Thursday, the session would be postponed to the day before or after that in accordance with the director's order.

Extraordinary sessions were obligatory for all the academicians. Non-members were allowed to take part only with an invitation from the board of managers in order to present their scientific research and get the opinion about it. Apart from public sessions on the first Thursday after Epiphany (the election of the new director and announcing the prizes) and on May 8 - the day of St. Stanislaus - there was another session on October 20, the birthday the founder, Stanisław Leszczyński. During these meetings the newly elected members or academicians gave their reception speeches. Moreover, every member was supposed to continue the research in his field of expertise and report on his progress during extraordinary sessions: soit pour l'enrichir de ses lumières, soit pour profiter des remarques de ses confrères. ${ }^{19}$

The members of the Society could publish their presented works in the sessions' records and printed materials called mémoires. The statute encouraged all members to keep in contact with other intellectuals both local and foreign in order to exchange thoughts with them. The professors of the famous historical university Pont-à-Mousson in Lorraine could present their scientific or literary works only during extraordinary sessions without the right of vote in the issues of the Society. According to the article XLI of the Statute, a member could be expelled by vote with the result of $2 / 3$ votes. It could happen for an offence against human dignity, against religion or politics or for creating and distributing political pamphlets.

\section{The operations of the Society}

The research topics of scientists chosen during the sessions were determined by the Statute and limited to the realms of natural science (sciences naturelles) and literature or fine arts (belles-lettres). The subject area was not specified because these intellectual fields were treated very widely.

The issues connected with religion and political matters were excluded from the sessions of the Society. ${ }^{20}$ Academicians were obligated to choose their own research field, to report their work to the Society, to present the fragments of their results and to listen to critique and opinions of the fellow members. Everybody worked with eagerness according to their abilities and possibilities. Based on the diaries of academicians, the main focus of their research was the preparatory work for a universal history of Lorraine. It was a collective enterprise described in the article XXXL of the Statute as the Universal history of Lorraine (Histoire politique et religieuse de la Lorraine).

Their interest in this topic can be documented by manuscripts from 1751 which can be found in the archives of the

$\begin{array}{ll}19 & \text { Statuts, p. } 100 . \\ 20 & \text { Iвidem, p. } 99 .\end{array}$ 
Academy. ${ }^{21}$ It included church history, the study of which was conducted by the lawyer François-Timothée Thibault mostly in questions concerning legal frameworks of religious life; the abbé Charles François Tervenus applied for work, too. The two men were responsible for the edition of Histoire ecclésiastique de Lorraine en générale. The clergymen Ernest Leslie and Joseph de Menoux expressed their willingness to describe the precise literary history of the city of Nancy and the duchy of Lorraine. The perpetual secretary Solignac, due to his function and close relations to king Stanisław (he was the king's personal secretary), chose the history of Poland ${ }^{22}$ and the reign of His Highness our Founder, which was clearly underlined. ${ }^{23}$ Unfortunately, after thirteen years the Society was able to finish only a part of this enormous workpiece about church history. The work titled Histoire des loix et usages de la Lorraine et du Barrois dans les matières bénéficiales (The History of the laws and customs of Lorraine and Bar in the beneficiary matters' was published in 1763 by the canon law specialist and one of the first academicians, the lawyer
François-Timothé Thibault. ${ }^{24}$ The author dedicated his work to the Polish king, the duke of Lorraine and Bar.

The section of physics (Physique générale) contained the following subject matters: thermal waters in the region, metal and salt mines, the sources of streams, the visible phenomena, botany, chemistry, anatomy. There were several people working on physics: Theodore-Charles Custine, Louis Elisabeth de la Vergne de Tressan, Joseph Gautier, Dominique-Benoît Harmand, Charles Joseph Bagard. The first two men suggested they would investigate everything connected with experimental physics, exactly the phenomena of electricity. It is worth mentioning that counts Tressan and Custine were the perfect men for this job and their work resulted in significant achievements. Joseph Gautier, a passionate engineer, studied mechanics and mathematics. The last of the scholars, Bagard, who was a court doctor of the king Stanislaw, committed himself to the history of the works of the famous doctors of Lorraine and to his notes about the medical practice and anatomy. ${ }^{25}$

21 The manuscripts are in the Solignac papers and some of the basic fields of reserch are also described there. Dossier Solignac, [no author], Archives de l'Académie de Stanislas, Nancy; Société Royale des Lettres, Sciences et Arts de Nancy - procès-verbaux, 1750-1754, vol. I, p. 179.

22 Solignac is an author of a piece The History of Poland in several volumes, which had a couple of editions in Europe. Dossier Solignac, Histoire générale de Pologne par Mr. le Chevalier de Solignac I-V, Paris 1750; Histoire générale de Pologne VI, Amsterdam-Leipzig 1780.

23 Solignac was an editor of the texts of the king Stanislaw: Pierre Joseph Solignac (ed.), S. Leszczyński, Oeuvres de Stanislas Bienfaisant, Paris 1763.

24 Thimotée-François Thibault, Histoire des loix et usages de la Lorraine et du Barrois dans les matières bénéficiales, Nancy 1763.

25 Dossier Solignac; [no number], Archives de l'Académie de Stanislas, Nancy, The direction can be also found in Société Royale des Lettres, Sciences et Arts de Nancy - procès-verbaux I, p. 179; fragments in Mémoires de la Société Royale I, p. 114-115. 
The foreign members were offered material concerning the topics of this major work of the Society. ${ }^{26}$ Additionally, every foreign member was supposed to present a reception speech at the occasion of their acceptance. Several new academicians with different interests joined the Society after some years. They were divided into two groups: one was working on Histoire des loix de Lorraine, and the other on Physique générale. ${ }^{27}$

\section{The typology of speeches}

The variety of the topics presented during the sessions of the Academy was really wide. Yet most of them belong to one of the following categories: Firstly, there were the speeches of the perpetual secretary (on topics related to his job), then the speeches of directors, the reception speeches and the reviews of the commission. These reviews reported on innovations in sciences et arts that were conducted by scientists outside the Academy. These reports consisted of a theoretical text and an empiric experiment. This was, for example, the case of a ship sailing against the current, pétrole blanc or several improved agriculture machines. There were also eulogy speeches presented after the deaths of outstanding French academicians, and panegyric speeches given by the panegyric clergymen during public sessions in May on the day of Saint Stanislaus.

\section{The research fields}

The research fields discussed in festive speeches were defined on the basis of the Statute of the Royal Society of Sciences and Literature in Nancy (Statuts de la Societé Royale des Sciences et Belles Lettres). ${ }^{28}$ By the "sciences" the Society understood natural sciences (sciences naturelles). This vague definition limited the scope of topics to various aspects of inanimate material world as seen through the lenses of mathematic methods. The absence of accurate definition caused many problems with a proper denomination of scientific disciplines. Some of the most important natural sciences were physics, mathematics, astronomy, biological sciences, medicine, geography, agriculture and economy.

The second part of the name of the Society refers to literature (belles-lettres). This notion was formulated in the first half of the $18^{\text {th }}$ century, the period of systematization of various writing forms. At that time, the term belles lettres meant poetic and oratory genres, epistolary and historiographic prose. ${ }^{29}$

There the name „art“ (arts) is difficult to classify. The term occurs quite often in the 1750 à 1793, in: Mémoires de l'Académie de Stanislas I.Nancy 1953, p. 130; M. Durbas, Akademia Stanistaw a, p. 223.

28 It is worth mentioning how the official name of the Society was formed because some publications of the time called it Société Royale des Sciences et des Arts à Nancy. 
reports on sessions, which related both to research and competition works. The term probably retained its medieval meaning. However, the words sciences et arts used by Stanisław Leszczyński himself referred to natural sciences. ${ }^{30}$ The notion was based on an entirely new definition explained by the writer and historian, Charles-Pinot Duclos in his work Considérations sur les moeurs de ce siècle (Considerations on the Habits of this Century). ${ }^{31} \mathrm{He}$ claimed that the aim of arts was to define the scientific achievements in craftsmanship and mechanical arts. It is important to underline that the king Stanisław Leszczyński understood the meaning of the term that was not defined precisely until the French Revolution. In 1794, abbé Grégoire, the alumnus of Jesuit order in Nancy from the monastery Missions Royales, the ward of the Solignac and the member of the Society, played an important role in creating the Museum of Arts and Trades (Musée des Arts et Metièrs). The establishment of this institution was a public recognition of the scientific status of applied art and industry.

\section{Research in the natural sciences (sciences naturelles)}

During the period discussed in the article, the field of sciences was understood as natural sciences. It was a very flexible category applied not only to phenomena of the animated world, but also to all kinds of industry and manual labour. The esprit scientifique, which characterized France of the middle of the $18^{\text {th }}$ century, grew from the esprit encyclopédique. It suggested that knowledge received directly or indirectly from the senses should be examined in experiments. The same spirit animated the Academy founded by the king Stanisław. Durival's work Mémoire sur la Lorraine et le Barrois from 1753 informs us about medical sciences which were called l'art de guérir (the art of curing). ${ }^{32}$ They included pharmacy and the art of surgery. Two doctors - Charles Bagard and Dominique-Benoît Harmand - were very active members of the Society in Nancy. They offered their participation at the very beginning and achieved good results. Bagard gave many speeches about medical science based on his own theories and empiric experiments.

At that time, natural sciences included also sections of physics as a science studying the outside world and experimental, theoretical and mathematical sciences. One of the representatives of this thought during the Enlightenment was abbé Joseph Gautier. The scope of his activities in the Society was really impressive. Between 1714 and 1775 he presented 22 speeches. He was well-known for his creative innovations such as the use of steam power for ships - an idea which brought him to the

30 The term sciences et arts was still used in $19^{\text {th }}$ century. See Tableaux synoptiques et annuels des procés- Verbaux de l'Académie de Stanislas 1750-1793, Bibliothèque Municipale à Nancy, ms. 920 (703) 1.

31 Charles Pinot Duclos, Considérations sur les moeurs de ce siècle, Paris 1750.

32 Nicolas Durival, Mémoire sur la Lorraine et le Barrois suivi de la table alphabétique et topographique des lieux, Nancy 1753, p. 72. 
attention of the Society. He tried his hand in various disciplines: he translated Aeneid, wrote a poem Sur la Lumière, invented bellows and new models of beehives, he won also the competition of orators at the Academy in Soissons in 1745. ${ }^{33}$

One of the first speeches in the Society was a reception speech delivered by count Custine on the day of king Stanisław Leszczyński's birthday, titled: The properties of the light from fire and electric fluid (Propriétés de la lumière du feu et du fluide electrique). ${ }^{34}$

\section{Research in literature (belles-lettres)}

The term belles lettres was coined in the first half of $18^{\text {th }}$ century at the time of systematization of various literary forms. The term was used to define the dominant aesthetic function of the language. The range of the belles lettres depended on the criteria of every historical period. It was difficult to differentiate this literature from other types of writing because there were many border genres. ${ }^{35}$ The term belles lettres was popularized thanks to the French historian and educator Charles
Rollin who wrote Traité des Etudes ${ }^{36}$ and the scholar abbé Charles Batteux, who wrote Cours de Belles-Lettres. ${ }^{37}$ According to the Polish scientist, Emmanuel Rostworowski, it was hard to distinguish the borders between academic, philosophic and journalistic writing and fiction, prose and poetry in the French literature of the middle of the $18^{\text {th }}$ century. ${ }^{38}$ The term belles-lettres meant poetic, oratory and rhetoric genres, epistolary and historiographic prose.

Among the genres presented during the sessions of the Society in Nancy by the academicians, as well as reception and occasional speeches, there were odes, theatrical plays, stories, descriptive poetry and satires. One of the first reception speeches (discours de receptions) submitted to the Royal Society in Nancy was Lysimaque by Charles-Louis de Secondant de Montesquieu who applied himself for the membership of the Society. ${ }^{39}$ The text was written, as the author emphasized, as a special academic contribution for the nascent institution in Nancy. It was submitted to the perpetual secretary in April

33 J. Allan Dainard, L'abbe Joseph Gautier (1714-1776), in: Jean-Claude Bonnefont (ed.), Stanislas et son Académie, Nancy 2003, p. 111-121.

34 Mémoires de la Société Royale II, p. 60.

35 J. SŁAwiński (ed.), Stownik terminów, p. 285.

36 Charles Rollin, De la manière d'etudier des Belles-Lettres par rapport à l'esprit et au coeur; ou traité des etudes I-IV, Paris 1726-1728.

37 Charles Batteux, Cours de Belles-Lettres distribuépar exercices, Paris 1747.

38 Emmanuel Rostworowski, Historia powszechna, Warszawa 1998, p. 421.

„Sire, j’appris hier chez M. Le maréchal de Belle-Isle que Votre Majesté venait d'établir une académie à Nancy, et ma première idée fut de lui demander une place: [...] Votre Majesté voit que je ne perds aucune des occasions qui peuvent un peu m'approcher d'elle."Société Royale des Lettres, Sciences et Arts de Nancy - procès-verbaux, vol. I, p. 139. 
1751 and presented for the first time in the public session in May that year. ${ }^{40}$

\section{The Prize contests}

The contests in the Stanisław Leszczyński Academy in the mid- $18^{\text {th }}$ century attracted both professionals and amateurs. They were open to men and women alike. These competitions were extremely important for the life of the Society. They were one of the most democratic scientific enterprises which made it possible to become a part of the educational efforts of the era. ${ }^{41} \mathrm{Un}$ doubtedly, the competitions and scientific awards were an important part of academic life of all the societies and academies in the Age of Enlightenment. ${ }^{42}$

The practice of prize contests, was criticized by many French scholars, ${ }^{43}$ but it was a very democratic project that allowed members of general public to present themselves to European scholars and laymen. The topics of the competition were divided into two research fields, which made the contest even more open than usual. The extraordinary quantity of the works submitted to the Society placed the Academy among the best provincial research centers in France. ${ }^{44}$ Even though the contestants were often not so wealthy as the enlightened elites, they worked hard and the Polish king often awarded them with the prize. The works submitted to the competition proved that the Enlightenment was evolving. The award from the Stanisław Leszczyński Academy in Nancy gave the contestants not only the financial prize, but also the respect of the people of Lorraine. The portrait of the prizewinning contestants increased their satisfaction and improved their reputation in the scientific circles.

This method of determining the research topics for the leading academicians in the Royal Society of Sciences and Literature in Nancy remained the same in the middle of the $18^{\text {th }}$ century. Generally, most of the works presented in the Society concerned natural sciences. Issues that animated scientific discussions of that time were connected to medicine, vaccinations, post-mortem examination and prolongation of human life. High mortality

40 The text of Lysimaque is printed in the first volume of the Mémoires de la Société Royale I, part II, p. 118-123.

41 Daniel Roche, Le siècle des lumières en province. Académies et academiciens provinciaux, 1680-1789, vol. I, Paris 1978; IDEM, Académies et académisme: le modèle français au XVIIIe siècle, Mélanges de l'Ecole française de Rome. Italie et Méditerranée 108, 1996, p. 643-658; Jeremy L. Caradonna, Prendre part au siècle des Lumières Le concours académique et la culture intellectuelle au XVIIIe siècle, Annales. Histoire, Sciences Sociales 64, 2009, p. 633-662. Available on: http://www.cairn.info/revue-annales-2009-3-page-633.html, [Accessed on 22. 2. 2018]; IDEM, The Enlightenment in Practice: Academic Prize Contests and Intellectual Culture in France 1670-1794, London 2012.

42 The competitions had either a regional or a transregional range, depending on the community connected with it. In Nancy it was a regional range. Małgorzata Durbas, Akademia Stanistawa, p. 255.

43 Karl Hildebrand, Les prix de l'Académie de Stanislas, contre-modèle regionaliste d'une institution européenne, in: Jean-Claude Bonnefont (ed.), Stanislas et son Académie, Nancy 2003, p. 303-315.

44 D. Roche, Le siècle des lumières en province, p. 330. 
was a major obstacle for the diffusion of knowledge because even outstanding minds of the era were not exempt from high mortality rates. Their death caused an irreplaceable loss. ${ }^{45}$ That was the reason why academic debates pertained to the prolongation of human life for ten years.

The inventions submitted for the prize contests could have been considered as irrational ideas, but today, we can assess their innovative potential. These inventions are for instance: a moving bolt ${ }^{46}$ or a steam-powered ship with the transmission of force on mechanical moving oars, ${ }^{47}$ navigational devices, air fresheners - the prototype of contemporary air conditioning - and many other valuable objects of artistic craft. ${ }^{48}$ The mechanical device for inland navigation that made it possible to move a ship up the river without using oars could seem to be as foolish as the use of steam power to drive ships. ${ }^{49}$ The case of the central heating stove was hard to understand because his practical usage had already been proven and it was still not given the feature of utility (utilitatis). The stove was able to heat even twenty rooms simultaneous1y. ${ }^{50}$ Obviously, not all inventions were really new. Academicians presented their own modified versions of various strange devices based on earlier conquests of science. That was how the progress emerged. There were works about electricity, sound, astronomical observations and historical or geographical descriptions. All of them helped the members to gain new knowledge, inspired them to new investigations and stimulated the rivalry between academicians.

It is necessary to understand that the middle of the $18^{\text {th }}$ century was the time when the Academy of Stanisław Leszczyński needed to become aware of the material reality, to open itself to opinions of the encyclopaedists, and learn to trust in the power of the mind and believe that humankind was constantly developing and evolving. The Royal Society of Sciences assembled the whole intellectual elite of Lorraine which became a lively and scientifically productive institution. It was a place of exchanging and confronting ideas, plus a center of creative critique. The bold investigations of new inventions that took place there were the driving force of scientific progress in the Age of the Enlightenment.

45 Pierre Chaunu, Cywilizacja wieku oświecenia, Warszawa 1989, p. 178.

46 Plan d'une hélice ou nouvelle vis mouvante, propre à être appliquée à plusieurs métiers, in: Mémoires de la Société Royale III, Nancy 1755.

47 Joseph Gautier, Mémoire sur la manière de suppléer à l'action du vent sur les vaisseaux in: Mémoires de la Société Royale II, Nancy 1755, p. 250-261. IDEM, Machine pour rafraichir l'air, in: Mémoires de la Société Royale II, p. 281-285.

49 [Stanisław Leszczyński], Nouvelles découvertes pour l'avantage et l'utilité du public, Nancy, chez Haener, Imprimeur ordinaire du Roi et de la Societé Royale, sur la Place de la Ville-Neuve au Nom de Jesus [sine dato], p. 42-51.

50 Iвidem, p. 32-40. 
Małgorzata Durbas

\section{The Organisation of Scientific Research at Leszczyński's Academy in Nancy (Abstract)}

The development of modern science outside university walls constituted the main reason of lack of coherence and difficulty in conveying thought, which created favourable conditions for establishing institutions under the patronage of influential and affluent people. The Académie de Stanislas Leszczyński in Nancy, which at the time of its establishment was called the Royal Society of Sciences and Literature, is the most long-lasting initiative of the Polish king, Stanisław I Leszczyński. This institution, founded in 1750, putting aside a little pause caused by the French Revolution, has been functioning till today. Pursuant to statute rules, scientific meetings dealt with research concerning natural sciences (sciences naturelles) and literature (belles-lettres). Scientific disciplines were not clearly defined as science was broadly understood at that time.

KEY WORDS

Scientific academies; associations; Stanisław Leszczyński; Nancy 